\title{
Lung Edema Clearance: Relevance to Patients with Lung Injury
}

\author{
Zaher S. Azzam, M.D. ${ }^{1}$ and Jacob I. Sznajder, M.D. ${ }^{2 *}$ \\ ${ }^{\prime}$ Internal Medicine "B", Rambam Health Care Campus, Department of Physiology and Biophysics, The \\ Rappaport Family Faculty of Medicine and Research Institute, Technion, Israel Institute of Technology, \\ Haifa, Israel; and ${ }^{2}$ Division of Pulmonary and Critical Care Medicine, Northwestern University, Chicago, \\ IL, USA.
}

\begin{abstract}
Pulmonary edema clearance is necessary for patients with lung injury to recover and survive. The mechanisms regulating edema clearance from the lungs are distinct from the factors contributing edema formation during injury. Edema clearance is effected via vectorial transport of $\mathrm{Na}^{+}$out of the airspaces which generates an osmotic gradient causing water to follow the gradient out of the cells. This $\mathrm{Na}^{+}$transport across the alveolar epithelium is mostly effected via apical $\mathrm{Na}^{+}$and chloride channels and basolateral $\mathrm{Na}, \mathrm{K}-$ ATPase. The Na,K-ATPase pumps $\mathrm{Na}^{+}$out of the cell and $\mathrm{K}^{+}$into the cell against their respective gradients in an ATP-consuming reaction. Two mechanisms contribute to the regulation of the Na,K-ATPase activity:recruitment of its subunits from intracellular compartments into the basolateral membrane, and transcriptional/translational regulation. Na,K-ATPase activity and edema clearance are increased by catecholamines, aldosterone, vasopressin, overexpression of the pump genes, and others. During lung injury, mechanisms regulating edema clearance are inhibited by yet unclear pathways. Better understanding of the mechanisms that regulate pulmonary edema clearance may lead to therapeutic interventions that counterbalance the inhibition of edema clearance during lung injury and improve the lungs' ability to clear fluid, which is crucial for patient survival.
\end{abstract}

KEY WORDS: Acute lung injury, alveolar epithelium, alveolar fluid clearance, Na,K-ATPase, pulmonary edema

\begin{abstract}
Abbreviations: AEC, alveolar epithelial cell; AFC, alveolar fluid clearance; AQP, aquaporin; $\beta 2 A R, \beta 2$-adrenergic receptor; CFTR, cystic fibrosis transmembrane conductance regulator; ENaC, epithelial $\mathrm{Na}^{+}$channel; $\mathrm{NHE}, \mathrm{Na}-\mathrm{H}$ exchanger; NSC, non-selective $\mathrm{Na}^{+}$channel.
\end{abstract}

Citation: Azzam ZS, Sznajder JI. Lung Edema Clearance: Relevance to Patients with Lung Injury. Rambam Maimonides Med J 2015;6 (3):eo025. doi:10.5041/RMMJ.10210

Copyright: (C) 2015 Azzam and Sznajder. This is an open-access article. All its content, except where otherwise noted, is distributed under the terms of the Creative Commons Attribution License (http://creativecommons.org/licenses/by/3.0), which permits unrestricted use, distribution, and reproduction in any medium, provided the original work is properly cited.

Conflict of interest: No potential conflict of interest relevant to this article was reported.

* To whom correspondence should be addressed. E-mail: j-sznajder@northwestern.edu 


\section{INTRODUCTION}

Pulmonary edema is a life-threatening condition of fluid excess in the lungs that causes impaired gas exchange with consequent symptoms that range from mild shortness of breath to acute respiratory failure. Approximately $56 \%$ of intensive care unit patients suffer from acute respiratory failure (ARF), with one-third of those subsequently dying. ${ }^{1}$ The pathogenesis of ARF can be classified to cardiogenic and non-cardiogenic pulmonary edema. Acute heart failure is the most common cause of increased hydrostatic pressure and is very prevalent, with almost 658,000 emergency department visits in the United States per year. The mortality rate from acute cardiogenic pulmonary edema ranges from $12 \%$ to $15 \% .^{2}$ In the USA, overall costs of heart failure in 2010 have been estimated at $\$ 39.2$ billion, with hospitalization representing approximately $80 \%$ of direct treatment costs for heart failure. 3

Acute lung injury (ALI) that is due to increased permeability pulmonary edema is also common, with an incidence of 86 per 100,000 person-years, and equates to over 190,000 cases and 74,500 fatalities annually in the United States. Although mortality has declined, recent studies still report an approximate $25 \%$ death rate. ${ }^{2}$

For many years, it was believed that fluid accumulation in the lung depends only on the abrogation of balanced Starling forces-the hydrostatic pressure and oncotic pressures.4,5 However, more recently it has been demonstrated that the alveolar epithelium has an active role in clearing edema out of the alveoli, a process called alveolar fluid clearance (AFC).

\section{LUNG STRUCTURE}

The lung is responsible for gas exchange: enriching the circulation with oxygen $\left(\mathrm{O}_{2}\right)$ and extruding carbon dioxide $\left(\mathrm{CO}_{2}\right)$. The structure of the lungs is designed to facilitate gas exchange by enabling the transit of gases through the respiratory airways, and, as the gases reach alveolar sacs and alveolus clusters, gas exchange actually occurs. The alveoli are tightly wrapped with blood vessels allowing the diffusion of oxygen from the alveoli to the bloodstream of the alveolar blood vessels. Then, oxygenated blood is perfused throughout the body where gas exchange occurs in the capillary beds. ${ }^{6}$

Since gas exchange relies on diffusion, it is crucial that the layer separating the alveolar space from the interstitium is thin and permeable. ${ }^{6}$ To ensure this environment, alveoli are built of a monolayer epithelium that contains two alveolar epithelial cells (Figure 1), types I and II (AECI and AECII, respectively), and macrophages. 7 Moreover, the alveolar space must be free of fluids and open. In utero, the fetal lung is filled with fluid that is removed shortly after birth, mainly because active reabsorption of sodium ions $\left(\mathrm{Na}^{+}\right)$across the alveolar epithelium creates an osmotic force favoring reabsorption of alveolar fluid. ${ }^{8}$

Alveolar epithelial cells type I are squamous with a diameter of about 50-100 $\mu \mathrm{m}$; however, they are very thin, thus minimizing the diffusion distance

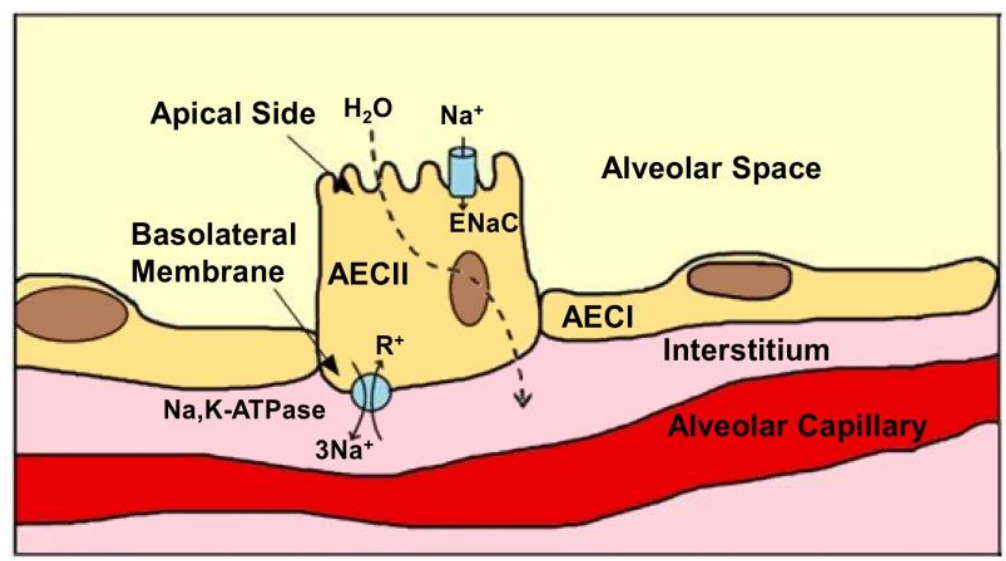

Figure 1. Schematic Representation of Alveolar Epithelial Cells with the Components that Contribute to the Alveolar Fluid Clearance Process.

$\mathrm{AECl}$, alveolar epithelial cell type I; AECII, alveolar epithelial cell type II; ENaC, epithelial $\mathrm{Na}^{+}$channel; $\mathrm{Na}, \mathrm{K}$ ATPase, sodium-potassium pump. 
between the alveolar airspace and the pulmonary capillaries, which facilitates gas exchange. Although they constitute $5 \%-10 \%$ of all lung cells, 9 AECI cover more than $90 \%$ of the alveolar surface as they are very large and have thin cytoplasmic extensions. Recently, it was reported that AECI play an active role in water permeability and the regulation of alveolar fluid homeostasis. ${ }^{10,11}$

The alveolar epithelial cells type II are smaller and cuboidal, with a diameter of $21 \mu \mathrm{m}$ in rats and $50 \mu \mathrm{m}$ in humans. They occupy only $\sim 5 \%$ of the surface area, yet AECII constitute $\sim 15 \%$ of all lung cells and $60 \%$ of alveolar epithelial cells. They produce, secrete, and recycle lung surfactant; they transport ions, participate in lung immune responses, and can also be converted to AECI to repair damaged epithelium or during fetal lung development. The AECII has a distinct morphology with characteristic lamellar bodies and a bipolar plasma membrane, consisting of an apical side that has short microvilli and a basolateral domain. These cells contain a wide range of transport proteins, including epithelial $\mathrm{Na}^{+}$channels (ENaCs), Na,KATPase, Na-H exchanger (NHE), and aquaporin-3 $(\mathrm{AQP} 3) \cdot{ }^{12-16}$

\section{HISTORIC PERSPECTIVE}

Normand et al. demonstrated that fetal lamb lungs can absorb fluid from the airspaces at birth, ${ }^{17}$ and by using ${ }^{131} \mathrm{I}$ tracer Walters and Olver calculated the rate of lung liquid secretion in fetal lambs. ${ }^{18}$ Matthay et al. reported that mature sheep lungs have the ability to clear edema. ${ }^{19}$ Since then, alveolar fluid clearance has been extensively investigated.4,20-25

\section{ALVEOLAR ACTIVE SODIUM TRANSPORT MECHANISM}

Alveolar fluid clearance (AFC) is an active process carried out mostly by the apical epithelial $\mathrm{Na}^{+}$ channels, and the basolateral Na,K-ATPase is involved in AFC. ${ }^{13,24}$

Briefly, $\mathrm{Na}^{+}$enters the alveolar epithelial cells through the apical amiloride-sensitive $\mathrm{Na}^{+}$channels $(\mathrm{ENaC})$, is transported through alveolar epithelial cells, and by a process that consumes energy is pumped out of the cell by the Na,K-ATPase located in the basolateral membrane in exchange for potassium entry in a ratio of $3: 2 \mathrm{Na}^{+}-\mathrm{K}^{+}$against their chemical gradient. This active vectorial $\mathrm{Na}^{+}$flux produces a transepithelial osmotic gradient that causes water to move from the airspaces following the gradient. ${ }^{8,26-28}$

Alveolar fluid reabsorption can be modulated by pharmacologic agents, gene therapy, and other interventions. Catecholamines, growth factors, vasopressin, aldosterone, overexpression of $\mathrm{Na}, \mathrm{K}$-ATPase subunits and chronic heart failure model increase alveolar fluid reabsorption (Figure 2A). ${ }^{16,29-40}$

Active $\mathrm{Na}^{+}$transport and edema clearance are inhibited by interventions that can be divided into several categories:

1. General AFC inhibitors such as the sodium channel blocker, amiloride, ${ }^{41}$ and the $\mathrm{Na}, \mathrm{K}$ ATPase inhibitor, ouabain. 5

2. Consequences of acute lung injury (ALI), hypoxia,42 and hypercapnia that impair the alveolar epithelial function by increasing intracellular calcium levels. 43,44

3. Mechanisms of ALI including sepsis,45 hyperoxia, ${ }^{46}$ high tidal volume ventilation and ventilation-induced lung injury, 47 acute left atrial hypertension, ${ }^{48}$ andendothelin (Figure 2).49

Notably, aerosolized or intravenous $\beta_{2}$-agonist therapy did not improve clinical outcomes in patients with lung injury; therefore, the use of $\beta_{2^{-}}$ agonist therapy was not recommended in mechanically ventilated patients with lung injury. ${ }^{50,51} \mathrm{~A}$ more recent study appears to shed light onto the disparate effect of $\beta_{2}$-agonist therapy in vitro in animals, and in patients with lung injury. Apparently, the $\beta_{2}$-adrenergic receptor $\left(\beta_{2} \mathrm{AR}\right)$ on alveolar macrophages can augment the release of IL6 , thus linking the sympathetic nervous system, by $32 \mathrm{AR}$ signaling, with lung inflammation and enhanced susceptibility to thrombotic cardiovascular events, which could have negative effects on the outcome of patients with acute lung injury..$^{2}$

Alveolar fluid clearance reflects active sodium transport, and several mediators participate in this process, including $\mathrm{Na}, \mathrm{K}-\mathrm{ATPase}, \mathrm{Na}^{+}$channels, aquaporins, and others. The sodium-potassium pump, an energy-consuming enzyme ( $\mathrm{Na}, \mathrm{K}-$ ATPase), is a heterodimeric integral membrane protein that is synthesized in polysomes related to the rough endoplasmic reticulum. It is composed of two subunits: an $\alpha$-subunit (a catalytic 110-kDa unit) and a $\beta$-subunit (a regulatory 55-kDa unit). The $\alpha-$ subunit contains binding sites for ATP hydrolysis, $\mathrm{Na}^{+}, \mathrm{K}^{+}$, and cardiac glycosides. There are at least 
three isoforms of $\alpha$ ( $\alpha 1, \alpha 2$, and $\alpha 3)$; they differ by their affinity to sodium, ouabain, and tissue distribution. The $\beta$-subunit is thought to be responsible for incorporating the $\alpha$-subunit into the plasma membrane; there are three known isoforms of $\beta$ subunit.
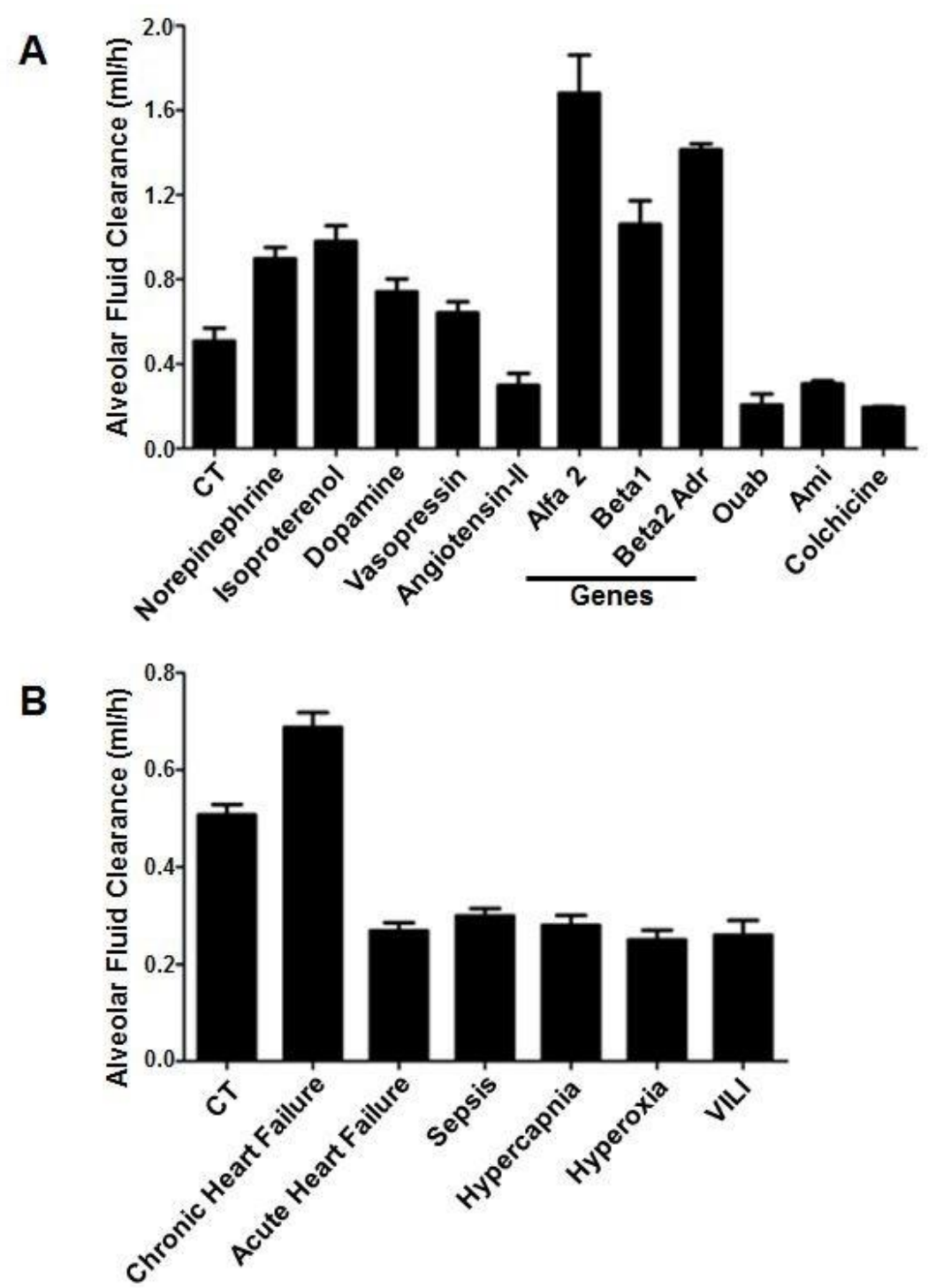

Figure 2. The Effect of Various Pharmacologic and Pathophysiologic Conditions on Alveolar Fluid Clearance. A: The rate of alveolar fluid clearance (AFC) was modulated following therapeutic interventions: catecholamines, vasopressin, and gene therapy upregulated AFC; however, the administration of endothelin, angiotensin, amiloride, ouabain, or colchicine inhibited active sodium transport and thus AFC. The data were adapted from references 13 , 27, 28, 31, 33, 36, 37.

B: Alveolar fluid clearance (AFC) was decreased in the various states of acute lung injury, such as sepsis, hyperoxia, hypercapnia, and ventilation-induced lung injury. Moreover, in rats exposed to acutely increased left atrial pressure (e.g. acute left heart failure) AFC was inhibited; whereas AFC was significantly upregulated in chronic heart failure rats. The data were adapted from references 34, 40-43.

The bars represent mean \pm SEM. Alfa2, a2-subunit of Na,K-ATPase; Ami, amiloride; beta1, B1-subunit of Na,KATPase; beta2 adr, B2 adrenergic receptor; CT, control; Ouab, ouabain; VILI, ventilation-induced lung injury. 
A critical role is played by $\mathrm{Na}, \mathrm{K}-\mathrm{ATPase}$ in the homeostasis of $\mathrm{Na}^{+}$and $\mathrm{K}^{+}$during altered salt intake and $\mathrm{pH}$ regulation, besides its other important functions in several organs; therefore it is strictly regulated. 8,53 The Na,K-ATPase can be regulated at the level of expression, internalization, and recruitment of the pump proteins to the basolateral membrane (Figure 3). For example, catecholamines enhance the ability of the lungs to clear edema by recruiting $\mathrm{Na}, \mathrm{K}-\mathrm{ATP}$ ase from the alveolar epithelial cell (AEC) cytosol to the basolateral membranes within minutes and thus increasing the activity of the pump. This process is mediated via the cAMP/PKA pathway. ${ }^{30,54,55}$ In contrast, the adverse effects on AFC of hypoxia, hypercapnia, sepsis, and endothelin are due to the AMPK/PKC pathway, in which Na,K-ATPase is phosphorylated, leading to its endocytosis. $42,45,49,56$

An important contributor to alveolar sodium transport is the sodium channel (ENaC). The ENaC is a heterotrimeric protein that can be composed by different combinations of three known subunits: $\alpha \mathrm{ENaC}, \beta \mathrm{ENaC}$, and $\gamma \mathrm{ENaC}$. Alveolar epithelial cells contain three types of channels with different selectivity properties: (1) a $\mathrm{Ca}^{2+}$-activated non-selective $\mathrm{Na}^{+}$channel (NSC) composed of $\alpha$-subunits alone, (2) a $\mathrm{Na}^{+}$-selective (moderately selective) channel composed of a combination of $\alpha \mathrm{ENaC}$ and $\beta \mathrm{ENaC}$ or $\gamma \mathrm{ENaC}$, and (3) the highly NSC composed of the three different subunits. The $\mathrm{ENaC}$ is located on the apical portion of AECs and plays a crucial role in sodium transport and AFC. ${ }^{28,30,57}$ Moreover, it has been shown that knocking out $\alpha \mathrm{ENaCleads}$ to defective AFC and premature death in newborn mice.

Water channels or aquaporins (AQPs) are expressed in the lungs. AQP1 is located in both the apical and basolateral aspects of endothelial cells and fibroblasts, and $\mathrm{AQP}_{3}, \mathrm{AQP}_{4}$, and $\mathrm{AQP}_{5}$ are expressed in the respiratory epithelium. In the human respiratory tract, $\mathrm{AQP}_{5}$ is expressed in the

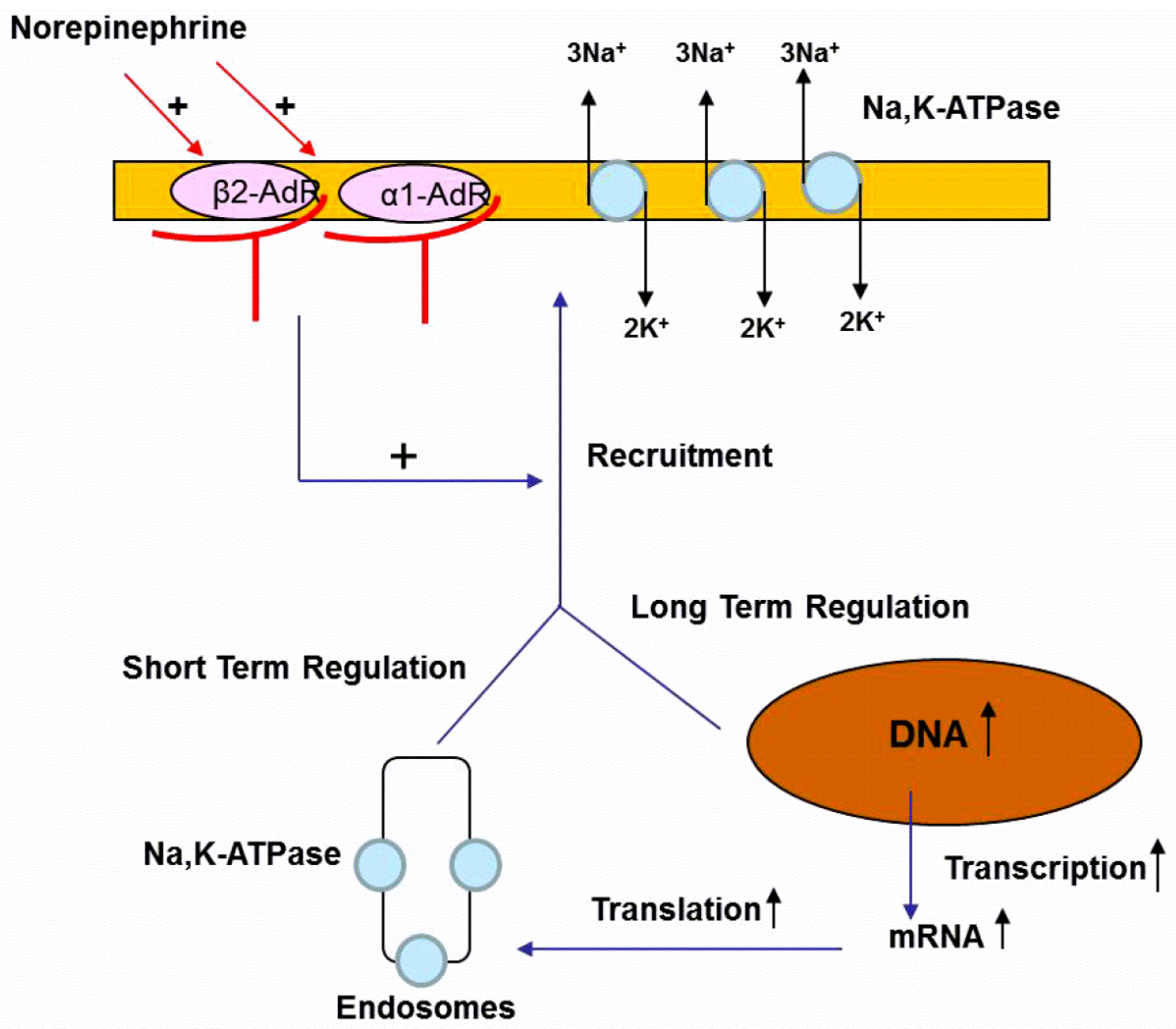

Figure 3. Schematic Representation of Active Sodium Transport in the Alveolar Epithelial Cell Depicting Apical $\mathrm{Na}^{+}$Channels, Basolaterally Located Na,K-ATPase, Aquaporins, and Co-transporters.

Sodium enters through the apical membrane via $\mathrm{Na}^{+}$channels and is extruded by the $\mathrm{Na}$, K-ATPase, with water following iso-osmotically. Proposed mechanisms by which norepinephrine upregulates active sodium transport and alveolar clearance. 
apical surface of AECI and AQP3 in the apical and basal membrane of AECII. Targeted deletions of AQPs in transgenic mice suggest that AQPs are not essential for alveolar fluid clearance; however, other compensatory mechanisms could have taken place instead of the deletion of AQPs. $5^{8}$

While the contribution of AECI to alveolar fluid clearance has been suggested, further studies to evaluate the role of distal epithelial cells are necessary. We also need to explore the role of chloride channels and their regulation, particularly in the pathways of activation as well as functional contributions of AQPs and cystic fibrosis transmembrane conductance regulator (CFTR). Additionally, signal transduction pathways as well as translation and post-translational pathways need to be studied as they may inform the field and help with novel therapies to modulate these pathways to enhance pulmonary edema clearance in patients with lung injury.

\section{CONCLUSIONS}

The mechanisms of lung edema clearance contrast with the regulation of pulmonary edema formation. Clearance of edema fluid is an active process that requires active transport of $\mathrm{Na}^{+}$out of alveolar airspaces, with water following the osmotic gradient. The regulation of vectorial $\mathrm{Na}^{+}$transport across the alveolo-capillary barrier is mediated mostly by apical $\mathrm{Na}^{+}$channels and basolaterally expressed $\mathrm{Na}, \mathrm{K}-\mathrm{ATPases}$. In patients with acute respiratory distress syndrome and lung injury the mechanisms regulating alveolar fluid reabsorption are impaired, and the restoration of the alveolar epithelial function to keep the lungs dry is important for normal gas exchange to occur and patients to survive. More knowledge about the mechanisms regulating lung edema clearance is needed in order to develop novel therapeutic strategies to accelerate fluid clearance and improve the alveolar epithelial function.

\section{REFERENCES}

1. Vincent JL, Akca S, De Mendonca A, et al. The epidemiology of acute respiratory failure in critically ill patients $\left({ }^{*}\right)$. Chest 2002;121:1602-9. Full Text

2. Mac Sweeney R, McAuley DF, Matthay MA. Acute lung failure. Semin Respir Crit Care Med 2011; 32:607-25. Full Text

3. Heidenreich PA, Albert NM, Allen LA, et al. Forecasting the impact of heart failure in the United
States: a policy statement from the American Heart Association. Circ Heart Fail 2013;6:606-19. Full Text

4. Berthiaume Y, Broaddus VC, Gropper MA, et al. Alveolar liquid and protein clearance from normal dog lungs. J Appl Physiol 1988;65:585-93.

5. Taylor AE, Guyton AC, Bishop VS. Permeability of the alveolar membrane to solutes. Circ Res 1965;16:35362. Full Text

6. Weibel ER. On the tricks alveolar epithelial cells play to make a good lung. Am J Respir Crit Care Med 2015;191:504-13. Full Text

7. Crandall ED, Matthay MA. Alveolar epithelial transport. Basic science to clinical medicine. Am J Respir Crit Care Med 2001;163:1021-9. Full Text

8. Sznajder JI, Factor P, Ingbar DH. Invited review: lung edema clearance: role of $\mathrm{Na}(+)-\mathrm{K}(+)$-ATPase. $\mathrm{J}$ Appl Physiol 2002;93:1860-6. Full Text

9. Stone KC, Mercer RR, Gehr P, et al. Allometric relationships of cell numbers and size in the mammalian lung. Am J Respir Cell Mol Biol 1992;6: 235-43. Full Text

10. Dobbs LG, Johnson MD, Vanderbilt J, et al. The great big alveolar TI cell: evolving concepts and paradigms. Cell Physiol Biochem 2010;25:55-62. Full Text

11. Gonzalez R, Yang YH, Griffin C, et al. Freshly isolated rat alveolar type I cells, type II cells, and cultured type II cells have distinct molecular phenotypes. Am J Physiol Lung Cell Mol Physiol 2005;288:L179-89. Full Text

12. Azzam ZS, Sznajder JI. The cellular mechanisms contributing to lung edema clearance. Isr Med Assoc J 2000;2:235-9.

13. Matalon S, Benos DJ, Jackson RM. Biophysical and molecular properties of amiloride-inhibitable $\mathrm{Na}+$ channels in alveolar epithelial cells. Am J Physiol 1996;271:L1-22.

14. Castranova V, Rabovsky J, Tucker JH, et al. The alveolar type II epithelial cell: a multifunctional pneumocyte. Toxicol Appl Pharmacol 1988;93:47283. Full Text

15. Mutlu GM, Sznajder JI. Mechanisms of pulmonary edema clearance. Am J Physiol Lung Cell Mol Physiol 2005;289:L685-95. Full Text

16. Ridge KM, Olivera WG, Saldias F, et al. Alveolar type 1 cells express the alpha2 Na,K-ATPase, which contributes to lung liquid clearance. Circ Res 2003;92: 453-60. Full Text

17. Normand IC, Olver RE, Reynolds EO, et al. Permeability of lung capillaries and alveoli to nonelectrolytes in the foetal lamb. J Physiol 1971;219: 303-30. Full Text 
18. Walters DV, Olver RE. The role of catecholamines in lung liquid absorption at birth. Pediatr Res 1978;12: 239-42. Full Text

19. Matthay MA, Landolt CC, Staub NC. Differential liquid and protein clearance from the alveoli of anesthetized sheep. J Appl Physiol 1982;53:96-104.

20. Serikov VB, Grady M, Matthay MA. Effect of temperature on alveolar liquid and protein clearance in an in situ perfused goat lung. J Appl Physiol 1993;75:940-7.

21. Smedira N, Gates L, Hastings R, et al. Alveolar and lung liquid clearance in anesthetized rabbits. J Appl Physiol 1991;70:1827-35.

22. Ballard ST, Schepens SM, Falcone JC, et al. Regional bioelectric properties of porcine airway epithelium. J Appl Physiol 1992;73:2021-7.

23. Effros RM, Mason GR, Sietsema K, et al. Pulmonary epithelial sieving of small solutes in rat lungs. J Appl Physiol 1988;65:640-8.

24. Rutschman DH, Olivera W, Sznajder JI. Active transport and passive liquid movement in isolated perfused rat lungs. J Appl Physiol 1993;75:1574-80.

25. Sakuma T, Okaniwa G, Nakada T, et al. Alveolar fluid clearance in the resected human lung. Am $\mathrm{J}$ Respir Crit Care Med 1994;150:305-10. Full Text

26. Berthiaume Y, Folkesson HG, Matthay MA. Lung edema clearance: 20 years of progress: invited review: alveolaredema fluid clearance in the injured lung. J Appl Physiol 2002;93:2207-13. Full Text

27. Borok Z, Verkman AS. Lung edema clearance: 20 years of progress: invited review: role of aquaporin water channels in fluid transport in lung and airways. J Appl Physiol 2002;93:2199-206. Full Text

28. Matalon S, Lazrak A, Jain L, et al. Invited review: Biophysical properties of sodium channels in lung alveolar epithelial cells. J Appl Physiol 2002;93: 1852-9. Full Text

29. Adir Y, Azzam ZS, Lecuona E, et al. Augmentation of endogenous dopamine production increases lung liquid clearance. Am J Respir Crit Care Med 2004; 169:757-63. Full Text

30. Azzam ZS, Adir Y, Crespo A, et al. Norepinephrine increases alveolar fluid reabsorption and $\mathrm{Na}, \mathrm{K}-$ ATPase activity. Am J Respir Crit Care Med 2004; 170:730-6. Full Text

31. Barnard ML, Olivera WG, Rutschman DM, et al. Dopamine stimulates sodium transport and liquid clearance in rat lung epithelium. Am J Respir Crit Care Med 1997;156:709-14. Full Text

32. Barquin N, Ciccolella DE, Ridge KM, et al. Dexamethasone upregulates the Na-K-ATPase in rat alveolar epithelial cells. Am J Physiol 1997;273: L825-30.

33. Berthiaume Y, Staub NC, Matthay MA. Betaadrenergic agonists increase lung liquid clearance in anesthetized sheep. J Clin Invest 1987;79:335-43. Full Text

34. Dumasius V, Sznajder JI, Azzam ZS, et al. beta(2)Adrenergic receptor overexpression increases alveolar fluid clearance and responsiveness to endogenous catecholamines in rats. Circ Res 2001;89:907-14. Full Text

35. Olivera WG, Ciccolella DE, Barquin N, et al. Aldosterone regulates $\mathrm{Na}, \mathrm{K}-\mathrm{ATPase}$ and increases lung edema clearance in rats. Am $\mathrm{J}$ Respir Crit Care Med 2000;161:567-73. Full Text

36. Saldias F, Lecuona E, Friedman E, et al. Modulation of lung liquid clearance by isoproterenol in rat lungs. Am J Physiol 1998;274:L694-701.

37. Azzam ZS, Adir Y, Welch L, et al. Alveolar fluid reabsorption is increased in rats with compensated heart failure. Am J Physiol Lung Cell Mol Physiol 2006;291:L1094-100. Full Text

38. Olivera W, Ridge K, Wood LD, et al. Active sodium transport and alveolar epithelial Na-K-ATPase increase during subacute hyperoxia in rats. Am J Physiol 1994;266:L577-84.

39. Guetta J, Klorin G, Tal R, et al. Vasopressin-2 receptor antagonist attenuates the ability of the lungs to clear edema in an experimental model. Am J Respir Cell Mol Biol 2012;47:583-8. Full Text

40. Azzam ZS, Dumasius V, Saldias FJ, et al. Na,KATPase overexpression improves alveolar fluid clearance in a rat model of elevated left atrial pressure. Circulation 2002;105:497-501. Full Text

41. Eaton DC, Chen J, Ramosevac S, et al. Regulation of $\mathrm{Na}+$ channels in lung alveolar type II epithelial cells. Proc Am Thorac Soc 2004;1:10-16. Full Text

42. Dada LA, Chandel NS, Ridge KM, et al. Hypoxiainduced endocytosis of Na,K-ATPase in alveolar epithelial cells is mediated by mitochondrial reactive oxygen species and PKC-zeta. J Clin Invest 2003; 111:1057-64. Full Text

43. Briva A, Vadasz I, Lecuona E, et al. High $\mathrm{CO}_{2}$ levels impair alveolar epithelial function independently of pH. PLoS One 2007;2:e1238.

44. Briva A, Santos C, Malacrida L, et al. Adenosine triphosphate-dependent calcium signaling during ventilator-induced lung injury is amplified by hypercapnia. Exp Lung Res 2011;37:471-81. Full Text

45. Berger G, Guetta J, Klorin G, et al. Sepsis impairs alveolar epithelial function by downregulating Na-KATPase pump. Am J Physiol Lung Cell Mol Physiol 2011;301:L23-30. Full Text 
46. Olivera WG, Ridge KM, Sznajder JI. Lung liquid clearance and $\mathrm{Na}, \mathrm{K}-\mathrm{ATPase}$ during acute hyperoxia and recovery in rats. Am J Respir Crit Care Med 1995;152:1229-34. Full Text

47. Lecuona E, Saldias F, Comellas A, et al. Ventilatorassociated lung injury decreases lung ability to clear edema in rats. Am J Respir Crit Care Med 1999;159: 603-9. Full Text

48. Saldias FJ, Azzam ZS, Ridge KM, et al. Alveolar fluid reabsorption is impaired by increased left atrial pressures in rats. Am J Physiol Lung Cell Mol Physiol 2001;281:L591-7.

49. Comellas AP, Briva A, Dada LA, et al. Endothelin-1 impairs alveolar epithelial function via endothelial ETB receptor. Am J Respir Crit Care Med 2009;179:113-22. Full Text

50. Gao Smith F, Perkins GD, Gates S, et al. Effect of intravenous beta-2 agonist treatment on clinical outcomes in acute respiratory distress syndrome (BALTI-2): a multicentre, randomised controlled trial. Lancet 2012;379:229-35. Full Text

51. Matthay MA, Brower RG, Carson S, et al. Randomized, placebo-controlled clinical trial of an aerosolized beta(2)-agonist for treatment of acute lung injury. Am J Respir Crit Care Med 2011;184:561-8. Full Text

52. Chiarella SE, Soberanes S, Urich D, et al. beta(2)Adrenergic agonists augment air pollution-induced
IL-6 release and thrombosis. J Clin Invest 2014;124: 2935-46. Full Text

53. Ackermann U, Geering K. Mutual dependence of $\mathrm{Na}, \mathrm{K}$-ATPase alpha- and beta-subunits for correct posttranslational processing and intracellular transport. FEBS Lett 1990;269:105-8. Full Text

54. Bertorello AM, Ridge KM, Chibalin AV, et al. Isoproterenol increases $\mathrm{Na}+-\mathrm{K}+-\mathrm{ATPase}$ activity by membrane insertion of alpha-subunits in lung alveolar cells. Am J Physiol 1999;276:L2O-7.

55. Ridge KM, Dada L, Lecuona E, et al. Dopamineinduced exocytosis of $\mathrm{Na}, \mathrm{K}-\mathrm{ATP}$ ase is dependent on activation of protein kinase C-epsilon and -delta. Mol Biol Cell 2002;13:1381-9. Full Text

56. Gusarova GA, Dada LA, Kelly AM, et al. Alpha1-AMPactivated protein kinase regulates hypoxia-induced $\mathrm{Na}, \mathrm{K}-\mathrm{ATP}$ ase endocytosis via direct phosphorylation of protein kinase C zeta. Mol Cell Biol 2009;29:345564. Full Text

57. Norlin A, Finley N, Abedinpour P, et al. Alveolar liquid clearance in the anesthetized ventilated guinea pig. Am J Physiol 1998;274:L235-43.

58. Dobbs LG, Gonzalez R, Matthay MA, et al. Highly water-permeable type I alveolar epithelial cells confer high water permeability between the airspace and vasculature in rat lung. Proc Natl Acad Sci U S A 1998;95:2991-6. Full Text 